\title{
Makalah Seminar Tugas Akhir PERANCANGAN SISTEM PENCATATAN TRAFO DISTRIBUSI BERBASIS MOBILE DEVICE DI PT PLN SALATIGA
}

\author{
Fira Nathania ${ }^{1)}$, Kodrat Iman Satoto ${ }^{2)}$, Kurniawan Teguh Martono ${ }^{2)}$ \\ Program Studi Sistem Komputer, Fakultas Teknik, Universitas Diponegoro \\ Jln. Prof. Sudharto, Tembalang, Semarang, Indonesia \\ Email: fira.nathania@yahoo.com
}

\begin{abstract}
Abstrak - Salah satu bagian penting dari jaringan listrik PT PLN (Persero) adalah keberadaan tranformator distribusi atau biasa disebut dengan trafo distribusi. Transformator distribusi merupakan peralatan utama dari jaringan distribusi PLN. Trafo distribusi ini memiliki tujuan penggunaan khusus yaitu untuk menurunkan tegangan tinggi ke tegangan rendah, agar tegangan yang dipakai sesuai dengan rating peralatan listrik pelanggan atau beban pada umumnya. Kerusakan pada trafo distribusi dapat mengganggu kelancaran pelayanan listrik kepada konsumen. Gangguan yang menyebabkan kerugian tersebut seperti pemutusan aliran listrik atau pemadaman yang dapat menyebabkan biaya-biaya pembangkitan meningkat tergantung harga KWH yang tidak terjual. Penempatan lokasi trafo distribusi yang tidak sesuai dapat mempengaruhi drop tegangan ujung pada konsumen atau jatuhnya/turunnya tegangan ujung saluran
\end{abstract} konsumen.Untuk menunjang pemeliharaan trafo distribusi, maka dibutuhkan data yang lengkap dari spesifikasi trafo distribusi tersebut beserta lokasi trafo-trafo distribusi yang dapat dikelola melalui Pengembangan Sistem Pencatatan Trafo Distribusi Berbasis mobile device di PT PLN Salatiga. Sistem pencatatan trafo distribusi terbagi menjadi tiga subsistem, yaitu aplikasi pencatatn trafo distribusi pada mobile device Android, sistem basis data, dan web trafodistribusipln.net63.net. Ketiga subsistem tersebut saling terintegrasi melalui pemrograman pertukaran data menggunakan PHP. Data-data yang dicatat melalui aplikasi pencatatan trafo distribusi pada mobile device Android antara lain : lintang, bujur, merek trafo, kapasitas trafo, lokasi trafo, tahun pembuatan trafo, deskripsi, dan petugas pencatatan trafo. Data-data tersebut akan disimpan di basis data MySQL, sehingga kemudian dapat diakses oleh pengguna baik melalui mobile device Android maupun melalui web trafodistribusipln.net63.net.

Pengujian dilakukan menggunakan metode black box testing. Hasil pengujian menunjukkan pertukaran data berjalan dengan baik dan komponen-komponen pada aplikasi dapat berfungsi sesuai fungsi yang diharapkan. Selain itu dilakukan pula pengujian terhadap keakuratan data lintang dan bujur dengan cara membandingkan data lintang dan bujur yang diambil melalui aplikasi pada mobile device Android dengan data lintang dan bujur yang didapatkan melalui GPS dengan merek 'Garmin'. Selisih hasil pengukuran lintang dan bujur menunjukkan nilai yang sangat kecil sehingga hal ini menunjukkan bahwa penentuan lokasi trafo distribusi berdasarkan pengukuran lintang dan bujur pada aplikasi pencatatan trafo distribusi pada mobile device Android memiliki hasil yang cukup akurat.

Kata kunci : Aplikasi Pertukaran Data Android, Trafo Distribusi, PT PLN, PHP, MySQL, GPS.

\section{PENDAHULUAN}

\subsection{Latar Belakang}

Listrik merupakan kebutuhan yang sangat penting bagi seluruh umat manusia di dunia ini. Melihat betapa pentingnya peran listrik dalam kehidupan manusia, maka jasa pengelola listrik di Indonesia juga dituntut untuk terus meningkatkan mutu dan kualitas pelayanannya. Salah satu bagian penting dari jaringan listrik PT PLN (Persero) adalah keberadaan tranformator distribusi atau biasa disebut dengan trafo distribusi. Transformator distribusi merupakan peralatan utama dari jaringan distribusi PLN. Trafo distribusi ini memiliki tujuan penggunaan khusus yaitu untuk menurunkan tegangan tinggi ke tegangan rendah, agar tegangan yang dipakai sesuai dengan rating peralatan listrik pelanggan atau beban pada umumnya. PT PLN dituntut untuk selalu melakukan pengontrolan dan pemeliharaan terhadap trafo-trafo distribusi. Selain untuk kepentingan PT PLN, pemeliharaan trafo distribusi juga tidak terlepas dari kepedulian PT PLN terhadap masyarakat untuk meminimalisir dampak dari kerusakan trafo dan optimalisasi kinerja trafo.

Setiap trafo distribusi memiliki data-data seperti merek trafo, kapasitas trafo, tahun pembuatan trafo, dan nomor seri trafo. Metode pencatatan data pada trafo distribusi selama ini masih dilakukan secara manual dan kurang terorganisir. Padahal data-data ini sangat membantu petugas dalam melakukan pengontrolan trafotrafo distribusi yang ada. Melalui tugas akhir ini, pencatatan data-data trafo distribusi tersebut ingin diwujudkan dalam suatu sistem informasi trafo dengan aplikasi mobile device. Aplikasi ini diharapkan dapat memudahkan petugas dalam melakukan pencatatan data trafo-trafo distribusi yang ada.

1.2 Rumusan Masalah

Berdasarkan latar belakang masalah tersebut, dapat dibuat suatu rumusan masalah yaitu:

"Bagaimana menciptakan aplikasi berbasis mobile device yang dapat memudahkan petugas PLN dalam melakukan pendataan terhadap trafo distribusi sehingga data-data tersebut dapat tersimpan dengan baik serta dapat diakses oleh kantor pusat PLN di wilayah layanan Salatiga?"

\subsection{Tujuan}

Tujuan penyusunan Tugas Akhir dengan judul "Perancangan Sistem Pencatatan Trafo Distribusi Berbasis Mobile Device di PT PLN (Persero) Salatiga" adalah : 
1. Membuat aplikasi berbasis mobile device Android yang mampu melakukan pencatatan data trafotrafo distribusi.

2. Membangun suatu media penyimpanan berupa basis data trafo distribusi, yang digunakan untuk inventarisasi data-data hasil pencatatan trafo distribusi berbasis mobile device Android.

3. Menjadikan data-data hasil pencatatan trafo distribusi berbasis mobile device Android sebagai acuan dalam pemeliharaan trafo-trafo distribusi berdasarkan lokasi dari setiap trafo distribusi yang didefinisikan sebagai nilai lintang dan nilai bujur hasil deteksi GPS.

4. Menjadikan data-data hasil pencatatan spesifikasi trafo distribusi berbasis mobile device Android sebagai acuan dalam melakukan perbaikan trafo apabila terjadi kerusakan trafo distribusi.

5. Mengintegrasikan sistem yang ada pada mobile device Android, sistem basis data dan sistem pada halaman web sehingga ketiga sistem tersebut menjadi satu sistem yang dinamis.

1.4 Batasan Masalah

Batasan masalah pada penelitian Tugas Akhir dengan judul "Perancangan Sistem Pencatatan Trafo Distribusi Berbasis Mobile Device di PT PLN (Persero) Salatiga" adalah :

1. Aplikasi pencatatan trafo distribusi berbasis mobile device ini berjalan pada platform Android.

2. Penelitian dan penerapan aplikasi ini dikhususkan untuk kantor pusat PT PLN (Persero) wilayah layanan Salatiga.

3. Pengujian dilakukan dengan mengambil data-data trafo distribusi yang tersebar di wilayah layanan PT PLN (Persero) Salatiga.

4. Dalam proses pengembangannya, aplikasi web basis data yang digunakan adalah PHP-MySQL.

5. Pengguna (user) yang dapat mengakses halaman web yang menampilkan data-data trafo distribusi adalah pengguna (user) yang memiliki hak akses khusus, baik yang memiliki level sebagai admin maupun yang memiliki level sebagai user.

\section{$2.1 \quad$ Android}

\section{DASAR TEORI}

Android SDK adalah tools API (Application Programming Interface) yang diperlukan untuk mulai mengembangkan aplikasi pada platform Android menggunakan bahasa pemrograman Java. Android merupakan subset perangkat lunak untuk ponsel yang meliputi sistem operasi, middleware dan aplikasi kunci yang di-release oleh Google. Saat ini disediakan Android SDK (Software Development Kit) sebagai alat bantu dan API untuk mulai mengembangkan aplikasi pada platform Android menggunakan bahasa pemrograman Java. Sebagai platform aplikasi-netral.

Android Development Tools (ADT) adalah plugin yang didesain untuk IDE Eclipse yang memberikan kita kemudahan dalam mengembangkan aplikasi dengan menggunakan IDE Eclipse. Dengan menggunakan ADT untuk Eclipse akan memudahkan kita dalam membuat aplikasi project android, membuat GUI aplikasi, dan menambahkan komponen-komponen yang lainnya, begitu juga kita dapat melakukan running aplikasi menggunakan Android SDK melalui eclipse. Dengan ADT , juga dapat dilakukan pembuatan package android (.apk) yang digunakan untuk distribusi aplikasi android yang dirancang.

Location Based Service (LBS) atau layanan berbasis lokasi adalah istilah umum yang digunakan untuk menggambarkan teknologi yang digunakan untuk menemukan lokasi perangkat yang digunakan. Salah satu unsur utama LBS adalah Location Providers (API Location) yang menyediakan teknologi pencarian lokasi yang digunakan oleh device/perangkat. API Location berhubungan dengan data GPS (Global Positioning System) dan data lokasi real-time. API location berapa pada paket android yaitu dalam paket android.location. Dengan Location Manager, kita dapat menentukan lokasi kita saat ini, Track gerakan/perpindahan, serta kedekatan dengan lokasi tertentu dengan mendeteksi perpindahan.[4]

\subsection{Client/Server}

Dengan makin berkembangnya teknologi jaringan komputer, sekarang ini ada kecenderungan sebuah sistem yang menggunakan jaringan untuk saling berhubungan. Dalam jaringan tersebut, biasanya terdapat sebuah komputer yang disebut server, dan beberapa komputer yang disebut client. Server adalah komputer yang dapat memberikan service ke server, sedangkan client adalah komputer yang mengakses beberapa service yang ada di server.

Ketika client membutuhkan suatu service yang ada di server, dia akan mengirim request kepada server lewat jaringan. Jika request tersebut dapat dilaksanakan, maka server akan mengirim balasan berupa service yang dibutuhkan untuk saling berhubungan menggunakan Socket.

Socket adalahsebuah endpoint untuk komunikasi didalam jaringan. Sepasang proses atau thread berkomunikasi dengan membangun sepasang socket, yang masing-masing proses memilikinya. Socket dibuat dengan menyambungkan dua buah alamat IP melalui port tertentu. Secara umum socket digunakan dalam client / server system, dimana sebuah server akan menunggu client pada port tertentu. Begitu ada client yang menghubungi server maka server akan menyetujui komunikasi dengan client melalui socket yang dibangun.[5]

\subsection{MySQL}

MySQL adalah salah satu program yang dapat digunakan sebagai basis data, dan merupakan salah satu software untuk basis data server yang banyak digunakan. MySQL bersifat Open Source dan menggunakan SQL. MySQL bisa dijalankan di berbagai platform misalnya Windows, Linux, dan lain sebagainya[2].

\section{$2.4 \quad$ PHP (PHP Hypertext Preprocessor)}

Untuk membuat website yang dinamis dan mudah di-update setiap saat dari browser, dibutuhkan sebuah program yang mampu mengolah data dari komputer client atau dari komputer server itu sendiri sehingga 
mudah dan nyaman untuk disajikan di browser, untuk melakukan semua itu bisa menggunakan pemrograman PHP.

PHP (PHP Hypertext Preprocessor) adalah bahasa pemrograman yang berjalan dalam sebuah webserver dan berfungsi sebagai pengolah data pada sebuah server. Dengan menggunakan program PHP, sebuah website akan lebih interaktif dan dinamis. Dalam menggunakan program PHP, sebuah website akan lebih interaktif dan dinamis. Dalam latihan buku ini penulisan script atau program PHP menggunakan program Adobe Dreamweaver CS5[2].

\subsection{Transformator Distribusi}

Gardu trafo distribusi berlokasi dekat dengan konsumen. Transformator dipasang pada tiang listrik dan menyatu dengan jaringan listrik. Untuk mengamankan transformator dan sistemnya, gardu dilengkapi dengan unit-unit pengaman. Karena tegangan yang masih tinggi belum dapat digunakan untuk mencatu beban secara langsung, kecuali pada beban yang didisain khusus, maka digunakan transformator penurun tegangan (step down) yang berfungsi untuk menurunkan tegangan menengah $20 \mathrm{kV}$ ke tegangan rendah 400/230Volt. Gardu trafo distribusi ini terdiri dari dua sisi, yaitu : sisi primer dan sisi sekunder. Sisi primer merupakan saluran yang akan mensuplay ke bagian sisi sekunder. Unit peralatan yang termasuk sisi primer adalah :

a. Saluran sambungan dari SUTM ke unit transformator (primer trafo).

b. Fuse cut out.

\section{c. Ligthning arrester.}

Tujuan dari penggunaan transformator distribusi adalah untuk mengurangi tegangan utama dari sistem distribusi listrik untuk tegangan pemanfaatan penggunaan konsumen. Transformator distribusi yang umum digunakan adalah transformator step-down $20 \mathrm{kV} / 400 \mathrm{~V}$. Tegangan fasa ke fasa sistem jaringan tegangan rendah adalah $380 \mathrm{~V}$. Karena terjadi drop tegangan, maka pada tegangan rendahnya dibuat diatas $380 \mathrm{~V}$ agar tegangan pada ujung penerima tidak lebih kecil dari $380 \mathrm{~V}$. Sebuah transformator distribusi perangkat statis yang dibangun dengan dua atau lebih gulungan digunakan untuk mentransfer daya listrik arus bolak-balik oleh induksi elektromagnetik dari satu sirkuit ke yang lain pada frekuensi yang sama tetapi dengan nilai-nilai yang berbeda tegangan dan arusnya. Transformator distribusi yang terpasang pada tiang dapat dikategorikan menjadi :

\section{$\square$ Conventional transformers}

$\square$ Completely self-protecting ( CSP ) transformers

$\square$ Completely self-protecting for secondary banking ( CSPB ) transformers. [9]

\section{$2.6 \quad$ A-GPS}

Assisted-Global Positioning System (A-GPS) merupakan penyempurnaan dari GPS sebagai satelit penentu posisi di belahan bumi. Satelit GPS yang dimiliki bumi mempunyai rasi bintang 24 satelit dalam enam orbit yang mendekati lingkaran, setiap orbit ditempati oleh 4 buah satelit dengan interval antara yang tidak sama. Orbit satelit GPS berinklinasi $550^{\circ}$ terhadap bidang equator dengan ketinggian rata-rata dari permukaan bumi sekitar $20.200 \mathrm{~km}$.

Metode Advanced Positioning yang terdapat pada A-GPS merupakan metode penentuan posisi yang paling tinggi akurasinya dibandingkan metode deteksi posisi lainnya seperti misalnya Time Difference of Arrival (TDOA), maupun Enhanced Observed Time Difference (E-OTD) sehingga A-GPS jauh lebih efisien dan efektif dalam mengakses informasi dari satelit karena tidak perlu mencari data satu persatu dari ke-24 satelit yang ada, namun A-GPS telah mengetahui sasaran (satelit) mana yang dibutuhkan atau dituju.[10]

\subsection{Metode Penelitian}

\section{PERANCANGAN SISTEM}

Penelitian pembuatan aplikasi pencatatan trafo distribusi berbasis mobile device Android dikembangkan secara sistematis melalui tahapan-tahapan berikut :

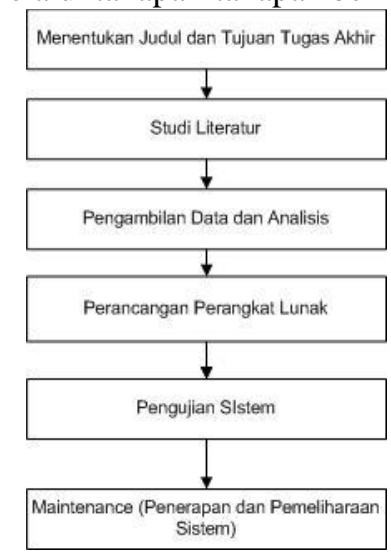

Gambar 1 Langkah-langkah penelitian pengembangan sistem pencatatan trafo distribusi berbasis mobile device Android

\subsection{Perancangan Perangkat Lunak}

Perancangan perangkat lunak aplikasi pencatatan trafo distribusi berbasis mobile device Android ini menggunakan model proses waterfall. Model proses ini dipilih karena pengembangan sistem dilakukan secara sekuensial.

\subsubsection{Analisis Kebutuhan}

Sistem pencatatan data-data trafo distribusi selama ini masih dilakukan secara manual. Pemindahan data ke basis data pun dilakukan secara manual. Hal ini membutuhkan waktu yang lebih lama dibandingkan apabila sistem sudah terintegrasi satu sama lain. Jika pencatatan data berbasis mobile device, dan data-data yang dicatat masuk ke basis data secara langsung, maka pencatatan trafo akan menjadi lebih teratur dan aliran data yang terjadi dapat dipantau dengan baik. Kemungkinan data hilang atau tercecer pun dapat diminimalisir. Penerapan sistem yang demikian juga akan menjawab keinginan manusia modern sehingga dapat melakukan pekerjaan dimana saja dan kapan saja. Selain itu hal-hal yang berkaitan dengan pencatatan data trafo menjadi lebih real time dan up to date.

\subsubsection{Kebutuhan Fungsional}

Dalam pembuatan aplikasi pencatatan trafo distribusi berbasis mobile device Android ini, spesifikasi 
kebutuhan fungsional harus ditetapkan dengan jelas. Hal -hal yang dibutuhkan dalam pencatatan trafo distribusi dirinci sehingga aplikasi ini menjadi optimal dan dapat memenuhi kebutuhan perusahaan secara tepat. Kebutuhan fungsional tersebut antara lain :

a. Kebutuhan fungsional pada aplikasi pencatatan trafo distribusi yang terdapat pada mobile device Android.

1. Aplikasi yang berada pada mobile device Android harus dapat mengidentifikasi user yang masuk ke sistem melalui form login dan memberikan hak akses sesuai dengan level yang dimiliki masingmasing user.

2. Form pencatatan trafo pada aplikasi Android harus dapat memasukkan data-data spesifikasi trafo distribusi dan menyimpan data-data tersebut ke dalam basis data.

3. Form pencatatan trafo yang terdapat pada aplikasi Android harus dapat melakukan pengambilan data lokasi berdasarkan lintang dan bujur yang didapatkan secara otomatis melalui bantuan GPS yang terpasang pada masing-masing mobile device Android dan menampilkan lokasi tersebut pada Google Maps.

4. Form pencatatan trafo dapat memberikan notifikasi kepada pengguna apabila GPS pada mobile device Android belum diaktifkan.

5. Setelah data berhasil tersimpan ke server, maka form pencatatan trafo harus dapat mengosongkan komponen-komponen edittext yang ada pada form tersebut.

6. Aplikasi pencatatan trafo distribusi dapat menampilkan daftar data trafo yang sesuai dengan data trafo distribusi yang sudah disimpan dalam basis data.

7. Aplikasi pencatatan trafo distribusi dapat menampilkan detail setiap data trafo yang sudah disimpan dalam basis data dan memungkinkan pengguna untuk melakukan perubahan terhadap data-data trafo distribusi, terkecuali data lintang dan bujur.

8. Aplikasi pencatatan trafo distribusi harus dapat menyimpan perubahan data trafo yang telah dilakukan oleh pengguna, dan menampilkan kembali data trafo yang telah diubah melalui list daftar trafo.

9. Menu utama pada aplikasi pencatatan trafo distribusi harus dapat mengarahkan pengguna ke masing-masing form yang dipilih pengguna. Form-form tersebut adalah form input trafo, form data trafo, dan form login apabila pengguna memilih pilihan logout.

a. Kebutuhan fungsional pada aplikasi pencatatan trafo distribusi yang terdapat pada halaman web..

1. User atau pengguna pada perangkat lunak pencatatan trafo distribusi dibedakan dalam dua kategori dengan level yang berbeda:

Admin (level admin)
- Pegawai PLN yang bertugas mencatat trafo / pengunjung biasa (level user)

2. Halaman web yang diakses oleh pengguna dengan level admin dapat menampilkan keseluruhan data trafo distribusi, memungkinkan admin menambahkan / mengubah / menghapus / mencari data trafo distribusi, memungkinkan admin mengelola data user, dan melihat lokasi trafo pada Google Maps.

3. Halaman web yang diakses oleh pengguna dengan level user dapat menampilkan keseluruhan data trafo distribusi dan memungkinkan user menambahkan/mencari data-data trafo distribusi, dan melihat lokasi trafo pada Google Maps.

\section{b. Keamanan sistem}

Keamanan dalam sistem ini didukung dengan adanya form login yang dilengkapi dengan user privileges, baik pada aplikasi yang berada pada mobile device Android, basis data MySql, juga pada halaman web. Disediakan form login yang terdiri dari username dan password untuk validasi. Username dan password tersebut masingmasing tersimpan di dalam basis data dan berguna untuk mengidentifikasi user atau pengguna yang memiliki hak akses untuk masuk ke setiap sistem berdasarkan level yang diberikan. Level tersebut meliputi level admin dan level user.

3.2.1.2 Kebutuhan Antarmuka

Kebutuhan antarmuka yang dimaksud disini meliputi kebutuhan perangkat lunak, kebutuhan perangkat keras, juga perangkat lain yang menghubungkan kedua perangkat tersebut.

a. Perangkat Lunak

Berikut adalah perangkat lunak yang digunakan dalam pembuatan aplikasi pencatatan trafo distribusi berbasis mobile device Android :

- Microsoft Windows 7 Pro

- Adobe Dreamweaver CS6

- $\quad$ Eclipse Helios version 3.6.2

- Android SDK (Android Development Tools-21.1.0)

- Emulator Android 4.0.3

- DDMS tools

- Xammp server

- phpMyAdmin

- $\quad$ Basis data $M y S q l$

- 000webhost.com

- $\quad$ Visual Paradigm for UML 10.2

- $\quad$ Microsoft Office Visio 2007

b. Perangkat Keras

Perangkat keras yang digunakan dalam pengembangan sistem pencatatan trafo berbasis mobile device Android antara lain sebagai berikut :

- 1 unit komputer dengan spesifikasi:

- Prosesor Intel (R) Atom(TM) CPU N550@1.50GHz 1.50 Ghz

- $\quad$ RAM 2 GB 
- $\quad$ System type 32-bit Operating System

- Tablet PC Advan Vandroid T2V

- Handphone CROSS A7S "HelloKitty"

- Handphone Android Samsung Galaxy ACE 2 GT-I8160

\subsubsection{Desain Sistem}

- GPS merek Garmin GPSMap 78s

Dalam tahap konseptualisasi, dijabarkan pemodelan dan alur sistem melalui diagram-diagram UML. Diagram-diagram UML yang telah dijabarkan akan dipakai dalam pembuatan sistem. Selain membantu pengembang sistem dalam mengembangkan sistem, penjabaran ini juga digunakan sebagai dokumentasi perancangan sistem.

\subsubsection{UML Diagram}

\section{a. Usecase Diagram}

Diagram ini menjelaskan keterkaitan aksi-aksi yang dilakukan oleh masing-masing aktor yang terlibat dalam sistem pencatatan trafo distribusi berbasis mobile device Android.

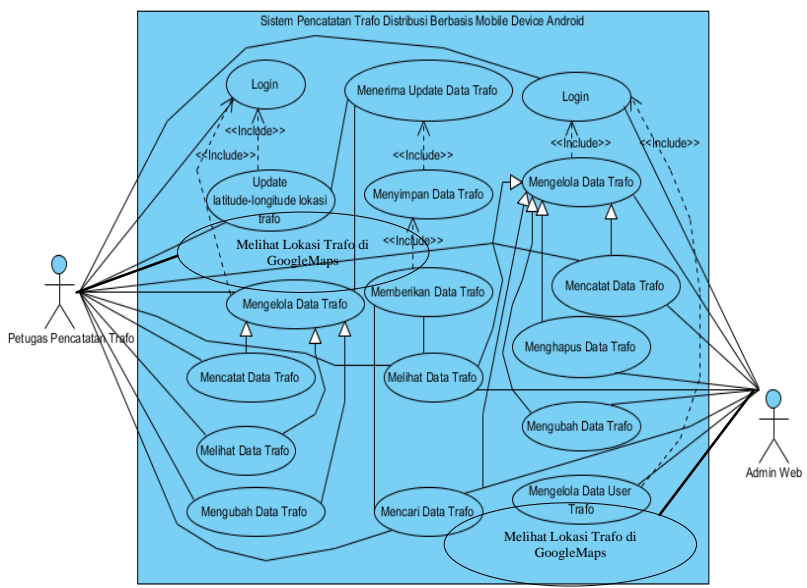

Gambar 2 Usecase diagram Sistem Pencatatan Trafo Distribusi Usecase diagram sistem pencatatan trafo pada gambar 2, memperlihatkan hal-hal apa saja yang dilakukan oleh setiap aktor yang terlibat dalam sistem pencatatan trafo distribusi. Aktor yang terlibat dalam sistem pencatatan trafo adalah:

1. Petugas pencatatan trafo distribusi yang menjalankan aplikasi pencatatan trafo distribusi di mobile device Android

2. Admin halaman web trafo distribusi.

Masing-masing aktor tersebut memiliki peran masing-masing. Petugas pencatatan trafo yang menjalankan mobile device Android dapat melakukan hal-hal berikut, yaitu:

a. Login ke dalam aplikasi pencatatan trafo yang terdapat di mobile device Android.

b. Mendapatkan data lintang dan bujur yang terambil secara otomatis dari hasil deteksi GPS yang terpasang di mobile device Android.

c. Melihat lokasi trafo distribusi melalui Google Maps.

d. Mencatat data-data trafo distribusi melalui form input yang ada pada aplikasi pencatatan trafo distribusi di mobile device Android. e. Melihat data-data yang sudah disimpan di dalam basis data yang ditampilkan melalui mobile device Android.

f. Mengubah atau mengedit data-data trafo distribusi yang telah disimpan dalam basis data melalui mobile device Android dan menyimpan kembali data-data trafo yang telah diubah.

b. Sequence Diagram

Sequence diagram merupakan diagram yang merepresentasikan urutan berjalannya sistem mulai dari user interface (dalam sistem ini bisa petugas pencatatan trafo atau admin web) kemudian masuk ke aplikasi, menuju ke koneksi basis data, sampai kembali lagi ke tangan pengguna. Sequence diagram dibuat berdasarkan usecase-usecase yang ada pada usecase diagram. Berikut adalah sequence diagram untuk masing-masing usecase yang terdapat dalam sistem :

- Sequence Diagarm untuk Usecase Login

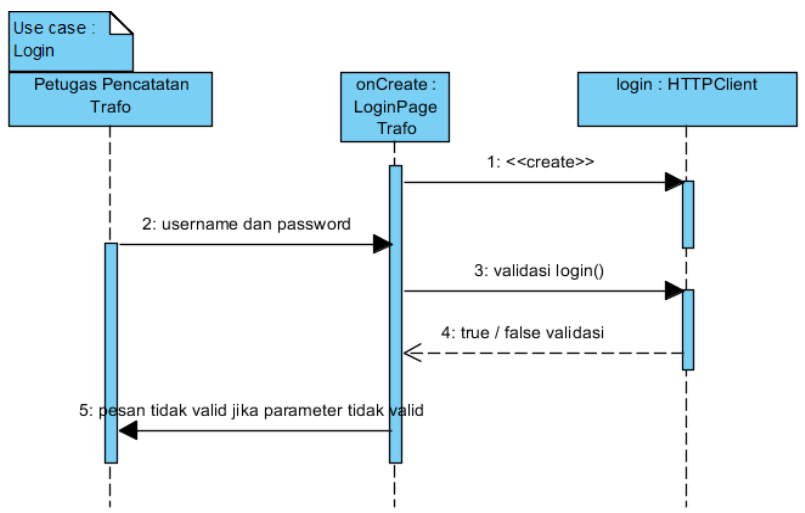

Gambar 3 Sequence diagram Login Sistem Pencatatan Trafo Distribusi Sequence diagram untuk usecase login memperlihatkan urutan proses ketika petugas pencatatan trafo distribusi login ke sistem. Username dan password yang dimasukkan melalui form Login Page Trafo divalidasi dan dicocokkan dengan username dan password yang ada di basis data melalui class HTTPClient yang tersambung ke file PHP yang terdapat pada web server.

- Sequence Diagram Usecase Memasukkan Data Sequence diagram memasukkan data memeperlihatkan ururtan proses petugas pencatatan trafo distribusi ketika memasukkan data-data trafo distribusi sampai data-data tersebut tersimpan di basis data MySql. 


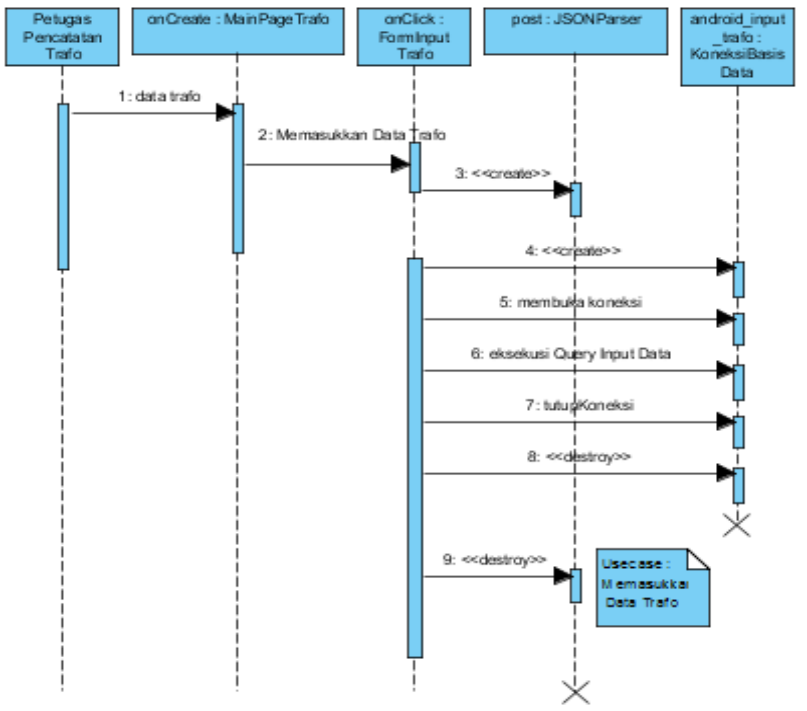

Gambar 4 Sequence diagram Memasukkan Data Sistem Pencatatan Trafo Distribusi

- Sequence Diagram untuk Usecase Mengubah Data Sequence diagram mengubah data memperlihatkan urutan proses ketika petugas pencatatan trafo distribusi melakukan perubahan data yang sudah tersimpan pada basis data MySql melalui aplikasi pada mobile device Android. Urutan tersebut juga mencakup keadaan ketika aplikasi mengambil data dari basis data dan menampilkannya pada form edit data pada aplikasi pencatatan trafo distribusi yang terdapat pada mobile device Android.

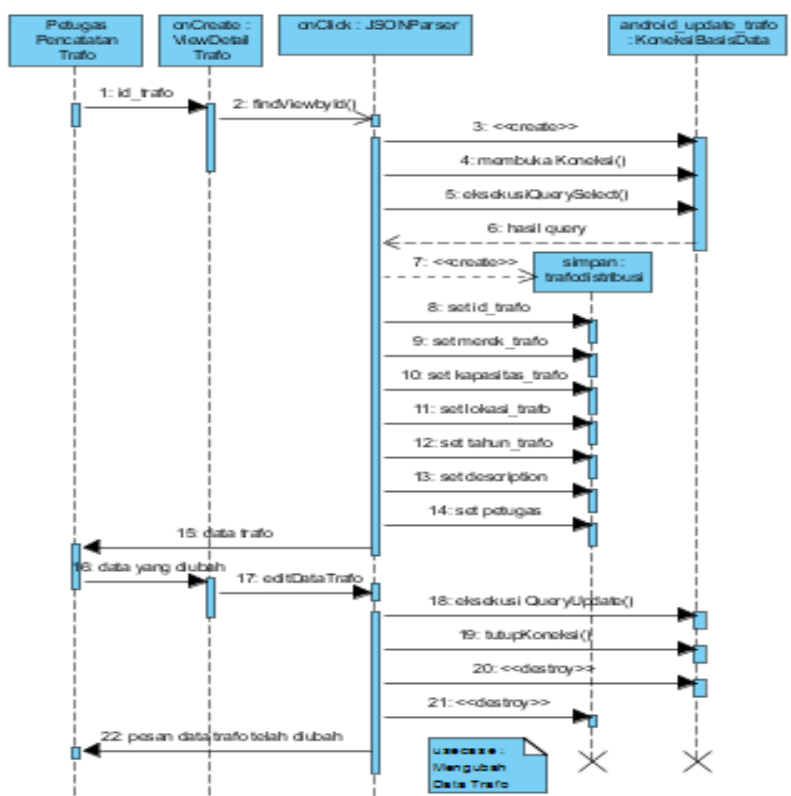

Gambar 5 Sequence diagram Mengubah Data Sistem Pencatatan Trafo Distribusi

\section{c. Statechart Diagram}

Statechart diagram merupakan diagram yang menggambarkan jalannya setiap proses dalam sistem yang ditandai dengan adanya status sistem dan dipicu oleh kegiatan yang dilakukan dalam proses transisi. Status sistem menggambarkan keadaan sistem sebelum ataupun sesudah transisi. Transisi ditandai dengan anak panah ke arah setiap status pada diagram. Transisi tersebut berupa sebuah kegiatan yang dilakukan oleh sistem untuk berpindah ke status berikutnya. Pada sistem ini, setiap action yang ada pada usecase diagram memiliki sebuah statechart diagram.

\section{- Statechart Login}

Statechart login memperlihatkan status sistem saat pengguna melakukan proses login. Trigger yang mempengaruhi transisi adalah username dan password yang dimasukkan oleh pengguna.

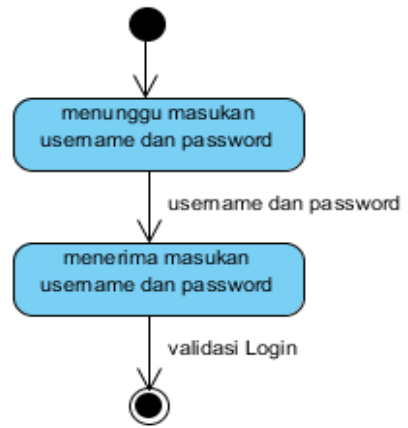

Gambar 6 Statechart Login Sistem Pencatatan Trafo Distribusi - Statechart Menu Utama

Statechart menu utama memperlihatkan status sistem ketika sebelum diberi masukkan berupa pilihan halaman yang hendak dituju. Halaman lain dari aplikasi yang akan dituju direpresentasikan ke dalam antarmuka menu utama yang berupa pilihan input data, data trafo, dan logout.

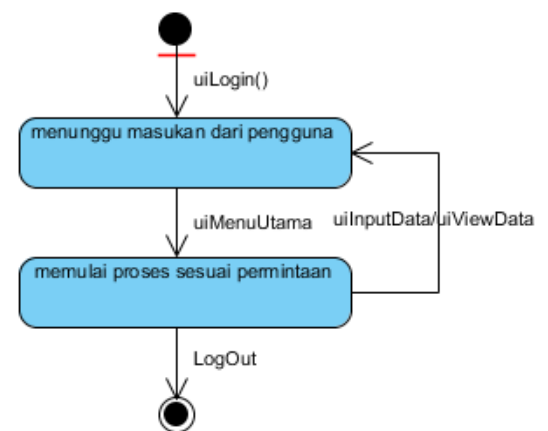

Gambar 7 Statechart Menu Utama Sistem Pencatatan Trafo Distribusi

\section{- Statechart Input Data}

Statechart input data trafo distribusi memperlihatkan status sistem ketika sebelum diberi masukkan berupa data-data trafo distribusi dan sesudah diberi masukan data-data trafo distribusi. Data-data trafo distribusi menjadi trigger dalam terjadinya transisi antar status sistem. Eksekusi button simpan juga menjadi trigger lain yang mempengaruhi status sistem.

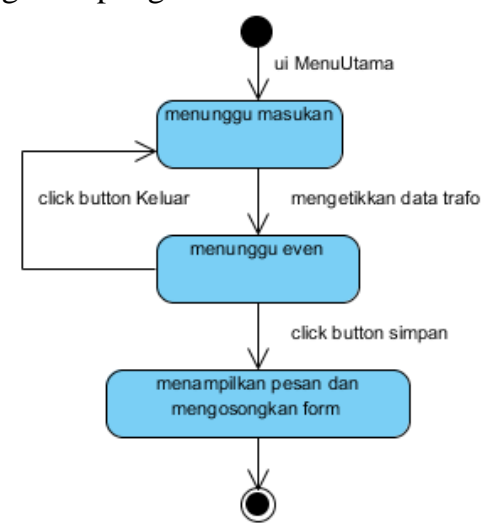


Gambar 8 Statechart Input Data Pencatatan Trafo Distribusi

\section{- Statechart Edit Data}

Statechart edit data trafo distribusi memperlihatkan apa saja yang dilakukan sistem ketika pengguna hendak mengubah data trafo yang sudah tersimpan di basis data. Statechart ini berawal dari kondisi sistem ketika berada pada halaman view data. Status pertama yang terlihat pada statechart adalah menunggu masukkan. Masukkan yang dimaksud adalah pemilihan salah satu data trafo yang terdapat pada daftar trafo distribusi. Data trafo distribusi yang dipilih akan diidentifikasi id-nya untuk dapat berlanjut ke status berikutnya. Status berikutnya berupa menampilkan form edit dan menunggu even, akan menampilkan detail data trafo distribusi sesuai dengan identifikasi id trafo distribusi yang telah terpilih,

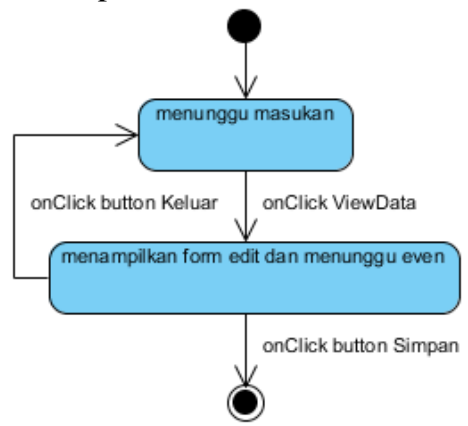

Gambar 9 Statechart Edit Data Sistem Pencatatan Trafo Distribusi

\section{- Statechart Koneksi Basis Data}

Statechart koneksi basis data merupakan statechart yang dapat terjadi lebih dari satu kali ketika sistem dijalankan. Hal ini dipengaruhi oleh banyaknya class atau aksi sistem yang secara langsung maupun tidak langsung terhubung ke basis data. Ketika sistem dimulai dengan mengeksekusi class login, sistem memvalidasi login user dengan koneksi basis data ke basis data MySql. Begitu pula dengan modul-modul lain seperti input data trafo, view data trafo, dan edit data trafo. Modul-modul tersebut akan menjalankan trigger berupa eksekusi Query Select / Query Update untuk berpindah ke status sistem berikutnya sesuai dengan fungsi masingmasing modul.

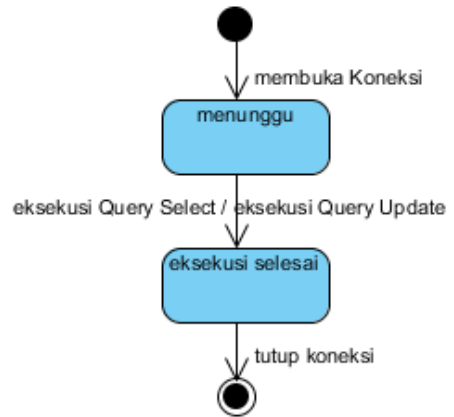

Gambar 10 Statechart Koneksi Database Sistem Pencatatan Trafo Distribusi

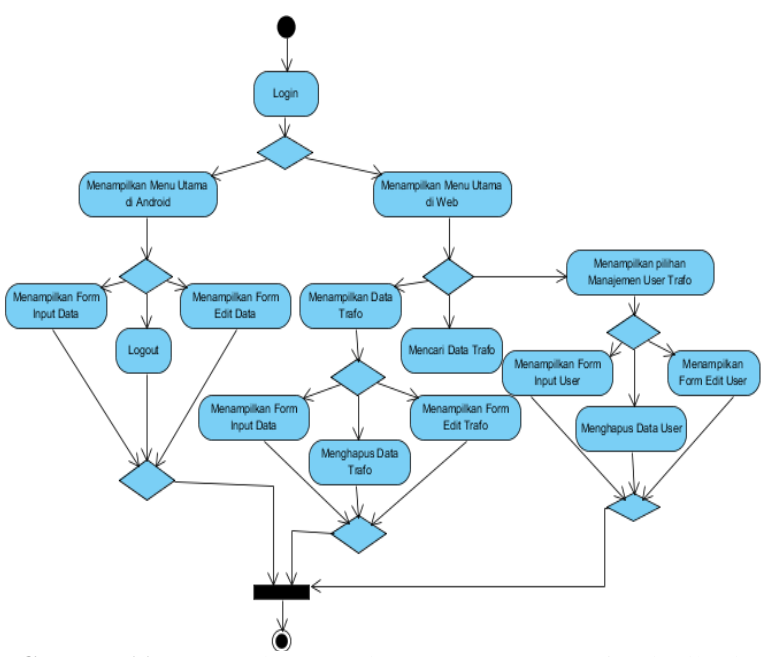

Gambar 11 Activity diagram Sistem Pencatatan Trafo Distribusi Activity diagram merupakan diagram yang menjabarkan aktivitas yang dilakukan oleh sistem. Berbeda dengan usecase yang menyoroti apa yang dilakukan oleh aktor, activity diagram merepresentasikan apa yang dilakukan sistem, misalnya menampilkan form login, menampilkan form input trafo, menampilkan data trafo dan hal-hal lain yang ditampilkan pada activity diagram diatas.

Activity diagram tidak hanya menggambarkan aktivitas sistem yang terjadi di mobile device Android, tetapi juga aktivitas yang terjadi pada sistem web. Jadi bisa dikatakan bahwa activity diagram menggambarkan hal-hal yang dapat dilakukan oleh keseluruhan sistem.

\section{e. Class Diagram}

Class diagram sistem pencatatan trafo distribusi yang ditunjukkan pada gambar 12, menjabarkan class apa saja yang terdapat dalam proses pengembangan sistem. Setiap class memiliki atribut-atribut yang digunakan dalam sistem. Atribut-atribut yang dimaksud antara lain seperti id trafo, data-data trafo lainnya, tombol simpan atau tombol keluar, username dan password untuk inisialisasi dan berbagai atribut lain yang telah ditunjukkan dalam class diagram pada gambar 12 . Sedangkan pada bagian bawah setelah garis pembatas dari setiap class merupakan operation atau constructor yang digunakan sistem dalam menginisialisasi atributatribut yang digunakan.

Selain itu, class diagram menggambarkan hubungan antar kelas yang digunakan dalam pengembangan aplikasi pencatatan trafo distribusi.Tanda positif menunjukkan bahwa atribut/operasi/konstruktor tersebut bersifat public, sedangkan tanda negatif menunjukkan bahwa atribut/operasi/konstruktor tersebut bersifat private

\section{d. Activity Diagram}




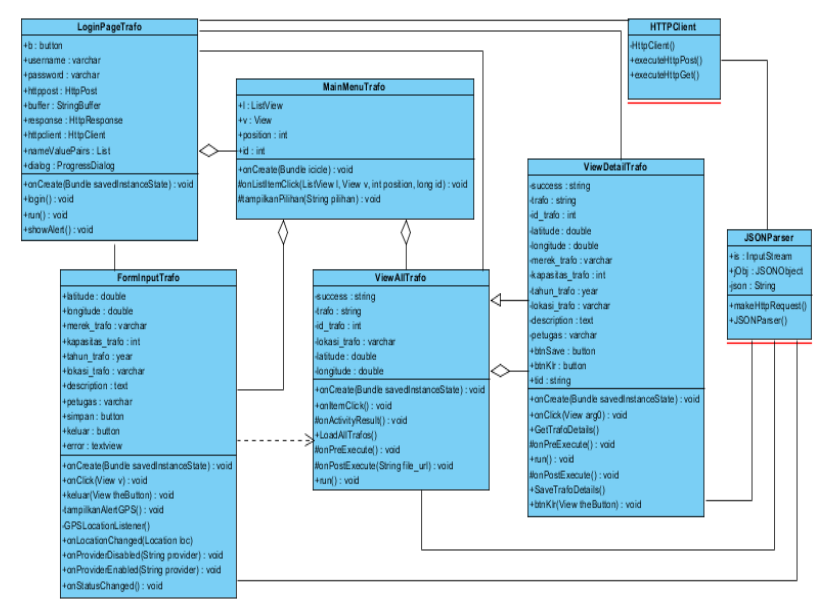

Gambar 12 Class diagram Sistem Pencatatan Trafo Distribusi 3.2.2.2 Perancangan Basis data

3.2.2.1 Basis Data

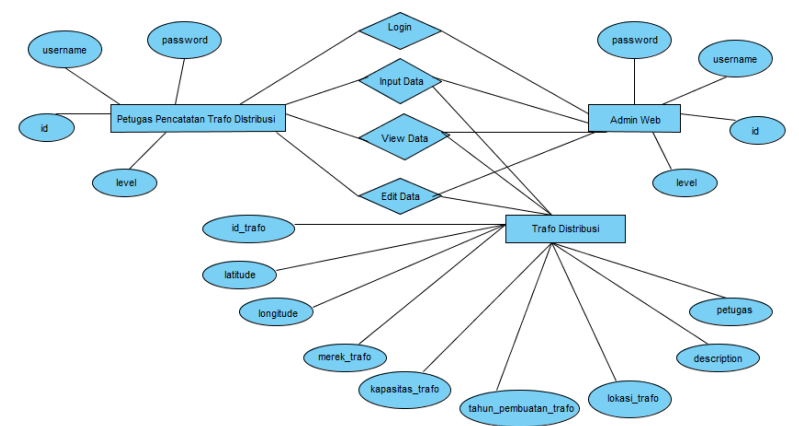

Gambar 13 Entity Relationship Diagram Sistem Pencatatan Trafo Distribusi

Sistem pencatatan trafo distribusi berbasis mobile device Android memerlukan basis data untuk menampung data-data yang disimpan dan diperlukan dalam melakukan proses pencatatan trafo dan pengelolaannya. Dalam sistem ini digunakan basis data MySql/phpMyAdmin dalam hal penampungan data. Terdapat dua buah tabel yang digunakan dalam menampung data. Penjelasan dari kedua tabel tersebut adalah sebagai berikut :

\subsection{Tabel tbl_user}

Tabel user atau pengguna merupakan tabel yang menampung data-data pengguna yang dapat mengkases aplikasi pada mobile device Android, maupun halaman website untuk pengelolaan trafo. Field-field yang terdapat dalam tabel tbl_user meliputi 'id' yang digunakan sebagai primary key dan memiliki extra action berupa Auto_increment. Auto_increment merupakan fungsi untuk menaikkan nilai dari content field 'id' setiap terjadi penambahan record. Field username dan password merupakan field yang digunakan untuk memvalidasi user-user yang mengakses sistem. Terdapat pula field level yang digunakan untuk menampung level pengguna. Level tersebut meliputi level admin dan level user. Berikut adalah tampilan tabel tbl_user beserta propertiesnya.

Tabel 1 Tabel tbl_user

\begin{tabular}{|c|c|c|c|}
\hline Field & type & Null & Extra \\
\hline Id & Int(11) & No & Auto_increment \\
\hline Username & Varchar(20) & No & \\
\hline Password & Varchar(32) & No & \\
\hline
\end{tabular}

\section{\begin{tabular}{l|l|l|} 
Level & Varchar(15) & No \\
\hline
\end{tabular}}

\subsection{Tabel trafodistribusi}

Tabel trafodistribusi merupakan tabel yang menampung seluruh data-data spesifikasi trafo distribusi. Field-field yang terdapat pada tabel trafodistribusi antara lain :

Tabel 2 Tabel trafodistribusi

\begin{tabular}{|c|c|c|c|c|}
\hline Field & Type & Null & Default & Extra \\
\hline Id_trafo & $\operatorname{Int}(11)$ & no & & $\begin{array}{l}\text { Auto_in } \\
\text { crement }\end{array}$ \\
\hline Latitude & double & yes & NULL & \\
\hline longitude & double & yes & NULL & \\
\hline Merek_trafo & $\begin{array}{c}\text { Varchar } \\
(100)\end{array}$ & yes & NULL & \\
\hline $\begin{array}{c}\text { Kapasitas_tr } \\
\text { afo }\end{array}$ & $\operatorname{Int}(5)$ & yes & NULL & \\
\hline Tahun_trafo & Year(4) & yes & NULL & \\
\hline Lokasi_trafo & $\begin{array}{c}\text { Varchar } \\
(100)\end{array}$ & yes & NULL & \\
\hline Description & text & yes & NULL & \\
\hline Petugas & $\begin{array}{c}\text { Varchar } \\
\text { (25) }\end{array}$ & yes & NULL & \\
\hline Created_at & $\begin{array}{c}\text { timesta } \\
\text { mp }\end{array}$ & no & $\begin{array}{c}\text { CURR } \\
\text { ENT_- } \\
\text { TIME } \\
\text { STAM } \\
\text { P }\end{array}$ & \\
\hline Updated_at & $\begin{array}{c}\text { timesta } \\
\text { mp }\end{array}$ & no & $00-00-0$ & \\
\hline
\end{tabular}

a. Id_trafo

Field id_trafo menampung nilai angka bertipe integer. Angka-angka ini selalu bertambah seiring dengan bertambahnya record pada tabel data_trafo dengan bantuan extra action auto_increment. Field id_trafo juga digunakan sebagai primary key yang membedakan satu trafo dengan trafo lainnya. Id_trafo juga digunakan sebagai field kunci dalam pemanggilan data baik saat menampilkan keseluruhan data trafo, detail data trafo, edit data trafo, dan delete data trafo dari sisi admin web.

\section{b. Lintang}

Field lintang dinamakan latitude pada tabel trafodistribusi ini. Field tersebut menampung nilai lintang sesuai dengan lokasi trafo distribusi. Field latitude memiliki tipe data double.

c. Bujur

Field bujur dinamakan longitude pada tabel trafodistribusi ini. Field tersebut menampung nilai bujur sesuai dengan lokasi trafo distribusi. Field longitude memiliki tipe data double.

d. Merek_trafo 
Field merek_trafo menampung merek trafo distribusi. Tipe data field merek_trafo berupa varchar dengan panjang 100.

e. Kapasitas_trafo

Field kapasitas trafo menampung data berupa angka yang menunjukkan kapasitas setiap trafo. Tipe data field kapasitas_trafo merupakan tipe data integer dengan panjang 5 .

f. Tahun_trafo

Field tahun_trafo menampung tahun pembuatan trafo, memilki tipe data year dengan panjang 4 .

g. Lokasi_trafo

Field lokasi_trafo menampung data alamat trafo yang sesuai dengan nilai lintang dan bujur yang diambil dengan bantuan GPS. Tipe data field lokasi_trafo adalah varchar dengan panjang 100.

h. Description

Field description merupakan field yang menampung data deskripsi dari keadaan trafo yang dicatat. Karena deskripsi memerlukan ruang tulis yang cukup banyak maka tipe data yang dipakai adalah text.

i. Petugas

Field petugas merupakan field yang menampung nama petugas yang melakukan pencatatan trafo distribusi melalui aplikasi yang berada pada mobile device Android.

j. Created_at

Field created_at akan mencatat tanggal saat data-data trafo tersimpan dalam basis data. Data tanggal pencatatan trafo akan terambil secara otomatis dengan bantuan tipe data timestamp. 


\section{k. Updated_at}

Field updated_at akan mencatat tanggal saat data-data trafo tersimpan dalam basis data setelah dilakukan update atau perubahan terhadap data-data trafo distribusi tersebut. Data tanggal perubahan trafo akan terambil secara otomatis dengan bantuan tipe data timestamp.

\section{ANALISIS DAN PEMBAHASAN}

\subsection{Analisis Perangkat Lunak}

Aplikasi pencatatan trafo distribusi berbasis mobile device Android ini dapat dijalankan pada mobile device Android yang menggunakan sistem operasi Android dengan versi minimum JellyBean. Versi-versi yang berada diatas versi JellyBean tersebut juga compatible dengan aplikasi pencatatan trafo distribusi berbasis mobile device Android ini. Selain sistem operasi dengan versi yang mendukung, fasilitas GPS yang dimiliki oleh mobile device Android harus memiliki pengaturan yang memungkinkan pengguna untuk mengaktifkan atau me-nonaktifkan GPS yang terpasang pada mobile device Android.

Dalam aplikasi pencatatan trafo distribusi berbasis mobile device Android ini, pertukaran data merupakan hal yang sangat penting dan sering dilakukan. Oleh karena itu diperlukan adanya koneksi internet untuk melayani pertukaran data yang dilakukan. Koneksi internet yang dimiliki oleh maisng-masing mobile device Android diharapkan untuk selalu stabil dan memiliki waktu akses yang cepat. Hal ini sangat diperlukan agar aplikasi dapat berjalan dengan baik sehingga ketika terjadi pertukaran data, semua data dapat terkirim dan diterima dalam bentuk yang sama. Jika koneksi lambat, maka kemungkinan error atau data korup menjadi lebih besar dan akan menghambat fungsionalitas dari aplikasi pencatatan trafo distribusi berbasis mobile device Android tersebut.

Aplikasi yang terdapat pada mobile device Android, memiliki fungsi-fungsi yang menunjang pengguna dalam melakukan pencatatan trafo distribusi. Fungsi-fungsi tersebut antara lain: login pengguna, mengambil nilai lintang dan bujur dan menampilkannya pada GoogleMaps, pencatatan spesifikasi data trafo, melihat keseluruhan data trafo, melihat detail data trafo, dan mengubah data trafo melalui mobile device Android. Fungsi-fungsi ini dapat dilihat dari modul-modul yang dimiliki aplikasi tersebut. Modul-modul yang terdapat pada aplikasi pencatatan trafo distribusi yang terdapat dalam mobile device Android antara lain 'Modul Form Login', 'Modul Menu Utama', 'Modul Form Input Trafo', 'Modul List All Trafo', 'Modul Form Edit Trafo'.

Halaman web trafo distribusi merupakan halaman web yang menampilkan data-data trafo distribusi yang tersimpan dalam basis data MySQL. Data-data yang ada atau tersimpan dalam basis data MySQL merupakan data-data yang telah disimpan melalui aplikasi yang terdapat pada mobile device Android maupun melalui web trafodistribusipln.net63.net.

Secara garis besar halaman web ini dibagi menjadi dua bagian, yaitu halaman untuk pengunjung biasa dan halaman untuk admin. Kedua bagian tersebut dibedakan oleh hak akses yang dimiliki oleh masing- masing pengguna yang menjalankan masing-masing bagian tersebut.

4.2 Analisis Perangkat Keras

Perangkat keras yang dimaksud dalam pembahasan ini adalah perangkat keras dimana aplikasi pencatatan trafo distribusi berbasis mobile device Android dapat berjalan. Spesifikasi minimum yang harus dipenuhi antara lain :

1. Handphone / tablet pc Android

2. Perangkat Android tersebut harus memiliki fasilitas GPS

3. Perangkat Android harus memiliki layanan koneksi ke Internet, baik menggunakan layanan wi-fi maupun paket data

4. Perangkat Android harus memiliki kapasitas memori yang cukup untuk menampung aplikasi pencatatan trafo distribusi berbasis mobile device Android beserta data-data yang terdapat di dalamnya.

4.3 Pengujian dengan Black Box

Pengujian aplikasi pencatatan trafo distribusi berbasis mobile device Android menggunakan metode pengujian black box. Metode pengujian black box merupakan metode pengujian yang berfokus pada persyaratan atau fungsional perangkat lunak.

Dalam pengujian dengan menggunakan metode pengujian black box ini, pihak yang menguji adalah pengguna sistem. Pengguna sistem yang dimaksud adalah petugas pencatatan trafo baik yang memiliki level user maupun admin.

Tabel 3 Hasil Pengujian aplikasi pencatatan trafo distribusi

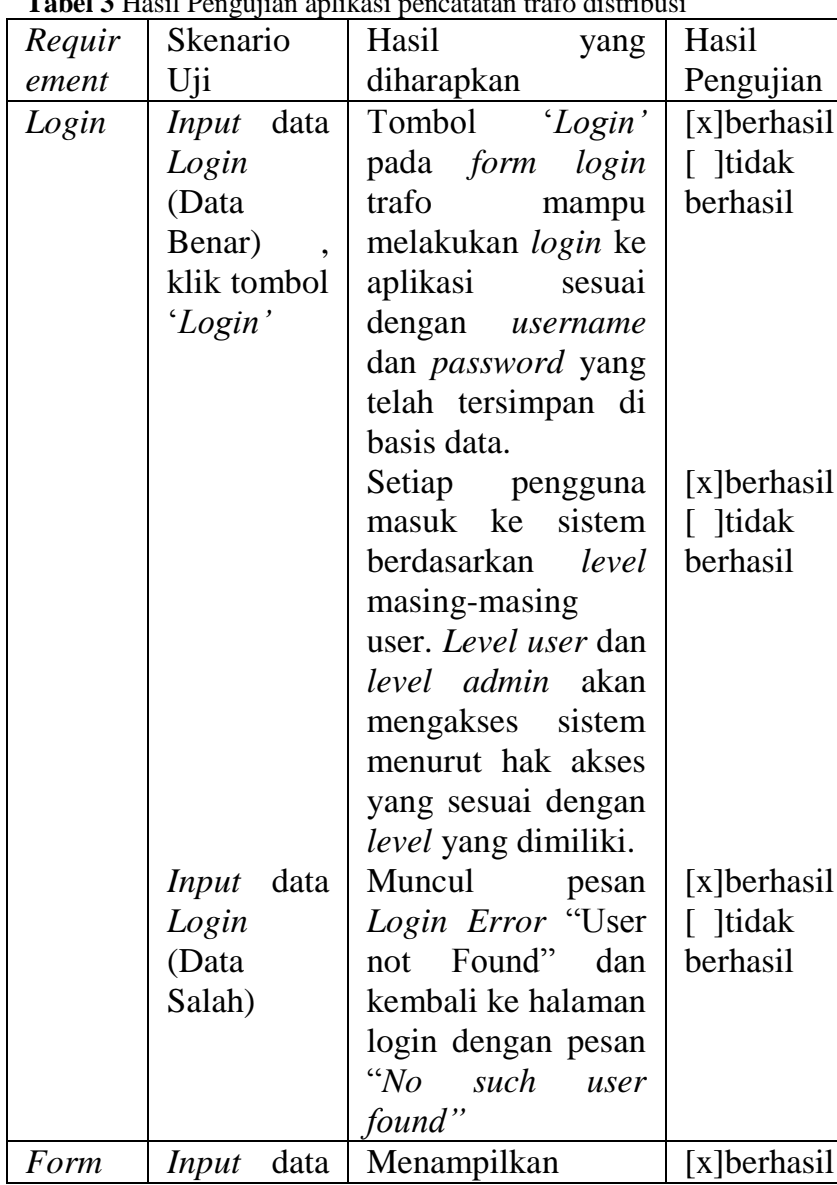




\begin{tabular}{|c|c|c|c|c|c|c|c|}
\hline \multirow[t]{3}{*}{$\begin{array}{l}\text { Input } \\
\text { Trafo }\end{array}$} & \multirow[t]{2}{*}{$\begin{array}{l}\text { spesifikasi } \\
\text { trafo } \\
\text { distribusi }\end{array}$} & \multirow{2}{*}{ 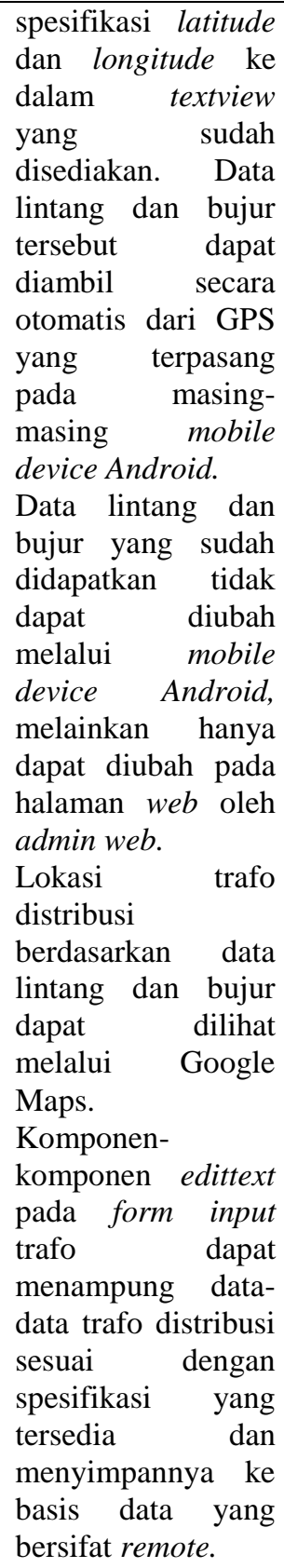 } & \multicolumn{2}{|l|}{$\begin{array}{l}\text { [ ]tidak } \\
\text { berhasil }\end{array}$} & $\begin{array}{l}\text { pada Menu } \\
\text { Utama } \\
\text { aplikasi } \\
\text { Memilih } \\
\text { pilihan } \\
\text { 'Data } \\
\text { Trafo' } \\
\text { pada Menu } \\
\text { Utama } \\
\text { aplikasi }\end{array}$ & 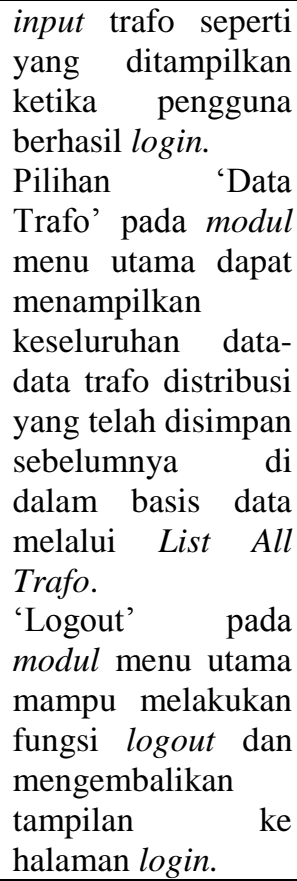 & $\begin{array}{l}{[\mathrm{x}] \text { berhasil }} \\
{[\text { ]tidak }} \\
\text { berhasil }\end{array}$ \\
\hline & & & $\begin{array}{l}{[\mathrm{x}] \text { berhasil }} \\
{[\text { ]tidak }} \\
\text { berhasil }\end{array}$ & $\begin{array}{l}\text { List All } \\
\text { Trafo }\end{array}$ & $\begin{array}{l}\text { Memilih } \\
\text { salah satu } \\
\text { data trafo } \\
\text { distribusi } \\
\text { yang } \\
\text { ditampilka } \\
\text { n pada list } \\
\text { all trafo }\end{array}$ & $\begin{array}{l}\text { Menampilkan form } \\
\text { edit data trafo } \\
\text { beserta nilai dari } \\
\text { spesifikasi yang } \\
\text { sesuai dengan id } \\
\text { trafo ketika salah } \\
\text { satu data trafo pada } \\
\text { List All Trafo } \\
\text { dipilih pada mobile } \\
\text { device Android. }\end{array}$ & $\begin{array}{l}\text { [x]berhasil } \\
\text { [ ]tidak } \\
\text { berhasil }\end{array}$ \\
\hline & $\begin{array}{l}\text { Simpan } \\
\text { data trafo } \\
\text { distribusi, } \\
\text { klik tombol } \\
\text { 'Simpan' }\end{array}$ & $\begin{array}{lr}\text { pada form } & \text { input } \\
\text { trafo dapat } & \text { data- } \\
\text { menampung } & \text { dengan } \\
\text { data trafo distribusi } & \text { sesuai yang } \\
\text { spesifikasi } & \text { dan } \\
\text { tersedia } & \text { menyimpannya ke } \\
\text { basis data yang } \\
\text { bersifat remote. } \\
\text { Tombol 'Simpan' } \\
\text { pada form input } \\
\text { trafo melakukan } \\
\text { fungsi yang sesuai } \\
\text { yaitu menyimpan } \\
\text { data-data } \\
\text { spesifikasi trafo } \\
\text { distribusi ke server. } \\
\text { Tombol 'Keluar' } \\
\text { mengarahkan } \\
\text { halaman dari form } \\
\text { input trafo menuju } \\
\text { ke modul menu } \\
\text { utama. }\end{array}$ & $\begin{array}{l}{[\mathrm{x}] \text { berhasil }} \\
\text { [ ]tidak } \\
\text { berhasil }\end{array}$ & $\begin{array}{l}\text { Form } \\
\text { Edit } \\
\text { Trafo }\end{array}$ & $\begin{array}{l}\text { Menyimpa } \\
\mathrm{n} \\
\text { perubahan } \\
\text { data trafo } \\
\text { distribusi , } \\
\text { klik tombol } \\
\text { 'Simpan' }\end{array}$ & $\begin{array}{l}\text { Tombol 'Simpan' } \\
\text { pada form edit trafo } \\
\text { mampu melakukan } \\
\text { perubahan apabila } \\
\text { nilai dari salah satu } \\
\text { / semua spesifikasi } \\
\text { data trafo yang } \\
\text { ditampung dalam } \\
\text { komponen edittext } \\
\text { pada form edit trafo } \\
\text { mengalami } \\
\text { perubahan dan } \\
\text { meng-update nya } \\
\text { pada basis data } \\
\text { yang bersifat } \\
\text { remote } \\
\text { Tombol 'Keluar' } \\
\text { pada form edit trafo } \\
\text { akan mengarahkan } \\
\text { halaman ke list all } \\
\text { trafo baik ketika } \\
\text { terjadi perubahan } \\
\text { data trafo distribusi } \\
\text { maupun tidak }\end{array}$ & $\begin{array}{l}\text { [x]berhasil } \\
\text { [ ]tidak } \\
\text { berhasil }\end{array}$ \\
\hline $\begin{array}{l}\text { Menu } \\
\text { Utama } \\
\text { Trafo }\end{array}$ & $\begin{array}{l}\text { Memilih } \\
\text { pilihan } \\
\text { 'Input }\end{array}$ & $\begin{array}{l}\text { Pilihan 'Input } \\
\text { Trafo' pada modul } \\
\text { menu utama dapat }\end{array}$ & $\begin{array}{l}\text { [x]berhasil } \\
\text { [ ]tidak } \\
\text { berhasil }\end{array}$ & & & $\begin{array}{l}\text { terjadi perubahan } \\
\text { pada data trafo } \\
\text { distribusi. }\end{array}$ & \\
\hline
\end{tabular}




\subsubsection{Pembahasan Hasil Pengujian}

Berdasarkan hasil pengujian uji sampel pada tabel 3, aplikasi pencatatan trafo distribusi berbasis mobile device Android dapat berjalan pada platform mobile dengan operating system Android versi Jellybean dan menampilkan hasil yang sesuai dengan hasil yang diharapkan.

4.4 Hasil Pengujian

Pengujian aplikasi pencatatan trafo distribusi berbasis mobile device Android dilakukan dengan mengimplementasikan aplikasi pada beberapa device dengan merek yang berbeda. Hal ini dilakukan untuk menguji keakuratan data lintang dan bujur yang dapat diambil oleh aplikasi. Ketiga data lintang dan bujur yang didapat, kemudian dibandingkan dengan data lintang dan bujur yang didapat melalui perangkat GPS dengan merek 'Garmin'. Berikut adalah data lintang dan bujur yang telah diambil melalui ketiga mobile device Android dan juga perangkat GPS 'Garmin' :

Tabel 4 Data lintang dan bujur hasil pencatatan trafo distribusi

\begin{tabular}{|c|c|c|c|c|}
\hline $\begin{array}{c}\text { Lokasi } \\
\text { Trafo }\end{array}$ & $\begin{array}{c}\text { GPS } \\
\text { Garmin }\end{array}$ & $\begin{array}{c}\text { Android } \\
\text { Ace2 }\end{array}$ & $\begin{array}{c}\text { Tablet } \\
\text { PC } \\
\text { Advan }\end{array}$ & $\begin{array}{l}\text { CROS } \\
\text { S A7S }\end{array}$ \\
\hline \multirow[t]{2}{*}{$\begin{array}{c}\text { Cungkup - } \\
\text { Yos } \\
\text { Sudarso }\end{array}$} & $-7,32033$ & 7,3 & $\begin{array}{l}7,3197 \\
8\end{array}$ & $\begin{array}{l}7,3206 \\
7\end{array}$ \\
\hline & $\begin{array}{l}110,5005 \\
3\end{array}$ & $\begin{array}{l}110,5004 \\
1\end{array}$ & $\begin{array}{l}110,49 \\
165\end{array}$ & $\begin{array}{l}110,50 \\
508\end{array}$ \\
\hline \multirow[t]{2}{*}{$\begin{array}{c}\text { Sayangan } \\
- \\
\text { Pattimura }\end{array}$} & $-7,32325$ & $-7,32311$ & $\begin{array}{l}- \\
7,3231 \\
4\end{array}$ & $\begin{array}{l}- \\
7,3232 \\
1\end{array}$ \\
\hline & $\begin{array}{l}110,5044 \\
6\end{array}$ & $\begin{array}{l}110,5042 \\
6\end{array}$ & $\begin{array}{l}110,50 \\
471\end{array}$ & $\begin{array}{l}110,50 \\
576\end{array}$ \\
\hline \multirow[t]{2}{*}{$\begin{array}{c}\text { Jendral } \\
\text { Sudirman } \\
\text { Ramayana }\end{array}$} & $-7,32498$ & $-7,32527$ & $\begin{array}{l}- \\
7,3251 \\
3 \\
\end{array}$ & $\begin{array}{l}- \\
7,3250 \\
1\end{array}$ \\
\hline & $\begin{array}{l}110,5049 \\
7\end{array}$ & $\begin{array}{l}110,5051 \\
7\end{array}$ & $\begin{array}{l}110,50 \\
305\end{array}$ & $\begin{array}{l}110,50 \\
124\end{array}$ \\
\hline \multirow[t]{2}{*}{$\begin{array}{l}\text { Jendral } \\
\text { Sudirman } \\
\text { BNI } 46\end{array}$} & $-7,32546$ & $-7,32532$ & $\begin{array}{l}- \\
7,3255 \\
0\end{array}$ & $\begin{array}{l}- \\
7,3253 \\
4\end{array}$ \\
\hline & $\begin{array}{l}110,5051 \\
9\end{array}$ & $\begin{array}{l}110,5051 \\
2\end{array}$ & $\begin{array}{l}110,50 \\
783\end{array}$ & $\begin{array}{l}110,50 \\
542\end{array}$ \\
\hline \multirow{2}{*}{$\begin{array}{c}\text { Perengrejo } \\
- \\
\text { Gendonga } \\
\mathrm{n}\end{array}$} & $-7,33569$ & $-7,33573$ & $\begin{array}{l}- \\
7,3357 \\
0 \\
\end{array}$ & $\begin{array}{l}- \\
7,3357 \\
2\end{array}$ \\
\hline & $\begin{array}{l}110,5081 \\
9\end{array}$ & $\begin{array}{l}110,5081 \\
2\end{array}$ & $\begin{array}{l}110,50 \\
766 \\
\end{array}$ & $\begin{array}{l}110,50 \\
796\end{array}$ \\
\hline \multirow[t]{2}{*}{$\begin{array}{c}\text { Jl. Jendral } \\
\text { Sudirman } \\
229\end{array}$} & $-7,34361$ & $-7,34357$ & $\begin{array}{l}- \\
7,3435 \\
8\end{array}$ & $\begin{array}{l}- \\
7,3436 \\
2\end{array}$ \\
\hline & $\begin{array}{l}110,5104 \\
0\end{array}$ & $\begin{array}{l}110,5112 \\
3\end{array}$ & $\begin{array}{l}110,51 \\
138\end{array}$ & $\begin{array}{l}110,51 \\
198\end{array}$ \\
\hline \multirow[t]{2}{*}{$\begin{array}{c}\text { Hasanudin } \\
576\end{array}$} & $-7,33861$ & $-7,33867$ & $\begin{array}{l}- \\
7,3386 \\
9\end{array}$ & $\begin{array}{l}- \\
7,3386 \\
3\end{array}$ \\
\hline & $\begin{array}{l}110,4959 \\
6\end{array}$ & $\begin{array}{l}110,4958 \\
1\end{array}$ & $\begin{array}{l}110,49 \\
611\end{array}$ & $\begin{array}{l}110,49 \\
520\end{array}$ \\
\hline $\begin{array}{c}\text { Hasanudin } \\
32 \\
\end{array}$ & $-7,33919$ & $-7,33925$ & $\begin{array}{l}- \\
7,3392\end{array}$ & $\begin{array}{l}- \\
7,3391 \\
\end{array}$ \\
\hline
\end{tabular}

\begin{tabular}{|c|c|c|c|c|}
\hline & & & 0 & 8 \\
\hline & $\begin{array}{l}110,4956 \\
6\end{array}$ & $\begin{array}{l}110,4955 \\
9\end{array}$ & $\begin{array}{l}110,49 \\
483\end{array}$ & $\begin{array}{l}110,49 \\
453\end{array}$ \\
\hline \multirow[t]{2}{*}{$\begin{array}{l}\text { Hasanudin } \\
100\end{array}$} & $-7,34284$ & $-7,33935$ & $\begin{array}{l}- \\
7,3398 \\
9\end{array}$ & $\begin{array}{l}- \\
7,3394 \\
0\end{array}$ \\
\hline & $\begin{array}{l}110,4936 \\
0\end{array}$ & $\begin{array}{l}110,4957 \\
8\end{array}$ & $\begin{array}{l}110,50 \\
390\end{array}$ & $\begin{array}{l}110,49 \\
653\end{array}$ \\
\hline \multirow[t]{2}{*}{$\begin{array}{l}\text { Veteran } \\
\text { NW }\end{array}$} & $-7,33822$ & $-7,33815$ & $\begin{array}{l}- \\
7,3381 \\
9\end{array}$ & $\begin{array}{l}- \\
7,3381 \\
8\end{array}$ \\
\hline & $\begin{array}{l}110,4999 \\
7\end{array}$ & $\begin{array}{l}110,5000 \\
7\end{array}$ & $\begin{array}{l}110,50 \\
067\end{array}$ & $\begin{array}{l}110,50 \\
052\end{array}$ \\
\hline \multirow[t]{2}{*}{$\begin{array}{l}\text { Ahmad } \\
\text { Yani } 65\end{array}$} & $-7,33446$ & $-7,33463$ & $\begin{array}{l}- \\
7,3345 \\
9\end{array}$ & $\begin{array}{l}- \\
7,3345 \\
0\end{array}$ \\
\hline & $\begin{array}{l}110,5016 \\
7\end{array}$ & $\begin{array}{l}110,5016 \\
4\end{array}$ & $\begin{array}{l}110,50 \\
103\end{array}$ & $\begin{array}{l}110,49 \\
968\end{array}$ \\
\hline \multirow[t]{2}{*}{$\begin{array}{l}\text { Diponegor } \\
\text { o } 112\end{array}$} & $-7,31861$ & $-7,30792$ & $\begin{array}{l}- \\
7,3078 \\
8\end{array}$ & $\begin{array}{l}- \\
7,3080 \\
0\end{array}$ \\
\hline & $\begin{array}{l}110,4969 \\
3\end{array}$ & $\begin{array}{l}110,4897 \\
0\end{array}$ & $\begin{array}{l}110,48 \\
909\end{array}$ & $\begin{array}{l}110,49 \\
090\end{array}$ \\
\hline \multirow[t]{2}{*}{$\begin{array}{l}\text { Diponegor } \\
\text { o } 66\end{array}$} & $-7,31902$ & $-7,31923$ & $\begin{array}{l}- \\
7,3191 \\
9\end{array}$ & $\begin{array}{l} \\
7,3192 \\
3\end{array}$ \\
\hline & $\begin{array}{l}110,4972 \\
9\end{array}$ & $\begin{array}{l}110,4975 \\
9\end{array}$ & $\begin{array}{l}110,49 \\
698 \\
\end{array}$ & $\begin{array}{l}110,49 \\
759\end{array}$ \\
\hline \multirow{2}{*}{$\begin{array}{c}\text { Diponegor } \\
\text { o 52-55 } \\
\text { (FEB } \\
\text { UKSW) }\end{array}$} & $-7,31906$ & $-7,32060$ & $\begin{array}{l} \\
7,3205 \\
5 \\
\end{array}$ & $\begin{array}{l} \\
7,3205 \\
3 \\
\end{array}$ \\
\hline & $\begin{array}{l}110,4973 \\
4\end{array}$ & $\begin{array}{l}110,4990 \\
9\end{array}$ & $\begin{array}{l}110,49 \\
833 \\
\end{array}$ & $\begin{array}{l}110,49 \\
803\end{array}$ \\
\hline \multirow[t]{2}{*}{$\begin{array}{c}\text { Adi } \\
\text { Sucipto }\end{array}$} & $-7,32795$ & $-7,33187$ & $\begin{array}{l}- \\
7,3318 \\
7\end{array}$ & $\begin{array}{l}- \\
7,3319 \\
9\end{array}$ \\
\hline & $\begin{array}{l}110,5005 \\
7\end{array}$ & $\begin{array}{l}110,4993 \\
2\end{array}$ & $\begin{array}{l}110,49 \\
932 \\
\end{array}$ & $\begin{array}{l}110,50 \\
112 \\
\end{array}$ \\
\hline \multirow[t]{2}{*}{ Semeru } & $-7,33279$ & $-7,33284$ & $\begin{array}{l}- \\
7,3323 \\
3\end{array}$ & $\begin{array}{l}- \\
7,3328 \\
0\end{array}$ \\
\hline & $\begin{array}{l}110,5034 \\
2\end{array}$ & $\begin{array}{l}110,5034 \\
9\end{array}$ & $\begin{array}{l}110,49 \\
580\end{array}$ & $\begin{array}{l}110,50 \\
288\end{array}$ \\
\hline \multirow[t]{2}{*}{ Semeru 8} & $-7,33222$ & $-7,33219$ & $\begin{array}{l}- \\
7,3322 \\
0 \\
\end{array}$ & $\begin{array}{l}- \\
7,3322 \\
2\end{array}$ \\
\hline & $\begin{array}{l}110,5034 \\
3\end{array}$ & $\begin{array}{l}110,5035 \\
0\end{array}$ & $\begin{array}{l}110,50 \\
365 \\
\end{array}$ & $\begin{array}{l}110,50 \\
395\end{array}$ \\
\hline \multirow[t]{2}{*}{$\begin{array}{l}\text { Pemotong } \\
\text { an33 }\end{array}$} & $-7,32955$ & $-7,32950$ & $\begin{array}{l} \\
7,3295 \\
3 \\
\end{array}$ & $\begin{array}{l} \\
7,3295 \\
0 \\
\end{array}$ \\
\hline & $\begin{array}{l}110,5034 \\
9\end{array}$ & $\begin{array}{l}110,5031 \\
8\end{array}$ & $\begin{array}{l}110,50 \\
363\end{array}$ & $\begin{array}{l}110,50 \\
318\end{array}$ \\
\hline \multirow{2}{*}{$\begin{array}{l}\text { Krekesan } \\
\text { (SD } \\
\text { Marsudiri } \\
\text { ni 78) }\end{array}$} & $-7,32578$ & $-7,32802$ & $\begin{array}{l}- \\
7,3280 \\
0\end{array}$ & $\begin{array}{l}- \\
7,3279 \\
3\end{array}$ \\
\hline & $\begin{array}{l}110,5022 \\
9\end{array}$ & $\begin{array}{l}110,5006 \\
2\end{array}$ & $\begin{array}{l}110,50 \\
031\end{array}$ & $\begin{array}{l}110,49 \\
926\end{array}$ \\
\hline Diponegor & $-7,32112$ & $\begin{array}{l}-7,32099 \\
\end{array}$ & & \\
\hline
\end{tabular}




\begin{tabular}{|l|l|l|l|l|}
\hline o 44 & & & $\begin{array}{l}7,3209 \\
8\end{array}$ & $\begin{array}{l}7,3210 \\
0\end{array}$ \\
\cline { 2 - 5 } & 110,4995 & 110,4995 & 110,49 & 110,49 \\
& 7 & 1 & 935 & 966 \\
\hline
\end{tabular}

Data-data lintang dan bujur yang telah diambil melalui mobile device Android dan perangkat GPS 'Garmin' dapat dibandingkan satu sama lain dengan cara menghitung selisih hasil pengukuran lintang dan bujur dari ketiga mobile device Android dengan hasil pengukuran lintang dan bujur dari GPS 'Garmin'.

Tabel 5 Perbandingan selisih data lintang dan bujur hasil pencatatan trafo distribusi pada mobile device Android dengan perangkat GPS Garmin.

\begin{tabular}{|c|c|c|c|}
\hline $\begin{array}{c}\text { Lokasi } \\
\text { Trafo }\end{array}$ & $\begin{array}{c}\text { Selisih } \\
\text { Android } \\
\text { Ace2 } \\
\text { dengan } \\
\text { GPS } \\
\text { Garmin } \\
\end{array}$ & $\begin{array}{c}\text { SelisihTable } \\
\text { t PC Advan } \\
\text { T2V dengan } \\
\text { GPS } \\
\text { Garmin }\end{array}$ & $\begin{array}{c}\text { Selisih } \\
\text { CROSS } \\
\text { A7S } \\
\text { dengan } \\
\text { GPS } \\
\text { Garmin } \\
\end{array}$ \\
\hline \multirow{2}{*}{$\begin{array}{c}\text { Cungkup - } \\
\text { Yos Sudarso }\end{array}$} & 0,00003 & $-0,00055$ & 0,00034 \\
\hline & 0,00012 & 0,00888 & $-0,00455$ \\
\hline \multirow{2}{*}{$\begin{array}{c}\text { Sayangan - } \\
\text { Pattimura }\end{array}$} & $-0,00014$ & $-0,00011$ & $-0,00004$ \\
\hline & 0,0002 & $-0,00025$ & $-0,0013$ \\
\hline \multirow{2}{*}{$\begin{array}{c}\text { Jendral } \\
\text { Sudirman } \\
\text { Ramayana }\end{array}$} & 0,00029 & 0,00015 & 0,00003 \\
\hline & $-0,0002$ & 0,0 & 0,00373 \\
\hline \multirow{2}{*}{$\begin{array}{c}\text { Jendral } \\
\text { Sudirman } \\
\text { BNI } 46\end{array}$} & $-0,00014$ & & $-0,00012$ \\
\hline & 0,00007 & $-0,($ & $-0,00023$ \\
\hline \multirow{2}{*}{$\begin{array}{c}\text { Perengrejo - } \\
\text { Gendongan }\end{array}$} & 0,00004 & 0,00001 & 0,00003 \\
\hline & 0,00007 & 0,00053 & 0,00023 \\
\hline \multirow{2}{*}{$\begin{array}{c}\text { Jl. Jendral } \\
\text { Sudirman } \\
229\end{array}$} & $-0,00004$ & 03 & 0,00001 \\
\hline & $-0,00083$ & & $-0,00158$ \\
\hline \multirow{2}{*}{$\begin{array}{c}\text { Hasanudin } \\
576\end{array}$} & 0,00006 & & 002 \\
\hline & 0,00015 & 15 & 0,00076 \\
\hline \multirow{2}{*}{$\begin{array}{c}\text { Hasanudin } \\
32\end{array}$} & 0,0 & & 001 \\
\hline & 0,00007 & 0,00083 & 0,00113 \\
\hline \multirow{2}{*}{$\begin{array}{l}\text { Hasanudin } \\
100\end{array}$} & $-0,00349$ & $-0,00295$ & $-0,00344$ \\
\hline & $-0,00218$ & $-0,0103$ & $-0,00293$ \\
\hline \multirow[t]{2}{*}{ Veteran NW } & $-0,00007$ & $-0,00003$ & $-0,00004$ \\
\hline & $-0,0001$ & $-0,0007$ & $-0,00055$ \\
\hline \multirow{2}{*}{$\begin{array}{l}\text { Ahmad } \\
\text { Yani } 65\end{array}$} & 0,00016 & 0,00013 & 0,00004 \\
\hline & 0,00003 & 0,00064 & 0,00199 \\
\hline \multirow{2}{*}{$\begin{array}{c}\text { Diponegoro } \\
112\end{array}$} & $-0,01069$ & $-0,01073$ & $-0,01061$ \\
\hline & 0,00723 & 0,00784 & 0,00603 \\
\hline \multirow{2}{*}{$\begin{array}{c}\text { Diponegoro } \\
66\end{array}$} & 0,00021 & 0,00017 & 0,00021 \\
\hline & $-0,0003$ & 0,00031 & $-0,0003$ \\
\hline \multirow{2}{*}{$\begin{array}{c}\text { Diponegoro } \\
52-55\end{array}$} & 0,00154 & 0,00149 & 0,00147 \\
\hline & $-0,00175$ & $-0,00099$ & $-0,00069$ \\
\hline \multirow[t]{2}{*}{ Adi Sucipto } & 0,00392 & 0,00392 & 0,00404 \\
\hline & 0,00125 & 0,00125 & $-0,00055$ \\
\hline \multirow[t]{2}{*}{ Semeru } & 0,00005 & $-0,00046$ & 0,00001 \\
\hline & $-0,00007$ & 0,00762 & 0,00054 \\
\hline \multirow[t]{2}{*}{ Semeru 8} & $-0,00003$ & $-0,00002$ & 0 \\
\hline & $-0,00007$ & $-0,00022$ & $-0,00052$ \\
\hline \multirow{2}{*}{$\begin{array}{c}\text { Pemotongan } \\
33 \\
\end{array}$} & $-0,00005$ & $-0,00002$ & $-0,00005$ \\
\hline & 0,00031 & $-0,00014$ & 0,00031 \\
\hline
\end{tabular}

\begin{tabular}{|c|r|r|r|}
\hline Krekesan & 0,00224 & 0,00222 & 0,00215 \\
\cline { 2 - 4 } & 0,00167 & 0,00198 & 0,00303 \\
\hline \multirow{2}{*}{$\begin{array}{c}\text { Diponegoro } \\
44\end{array}$} & $-0,00013$ & $-0,00014$ & $-0,00012$ \\
\cline { 2 - 4 } & 0,00006 & 0,00022 & $-0,00009$ \\
\hline
\end{tabular}

Keakuratan hasil pengukuran lintang dan bujur yang didapatkan ternyata menunjukan nilai yang cukup akurat. Keakuratan ini dapat dilihat dari nilai selisih antara hasil pengukuran lintang dan bujur dari ketiga mobile device Android dengan hasil pengukuran lintang dan bujur dari GPS 'Garmin' yang ternyata menunjukkan nilai yang sangat kecil. Untuk dapat membandingkan nilai-nilai tersebut dengan tepat, maka digunakan perhitungan statistik dalam menentukan nilai selisih ratarata, selisih maksimal, dan selisih minimal. Nilai-nilai tersebut dapat dilihat pada tabel 6 dan 7 .

Tabel 6 Perbandingan statistik selisih data lintang dan bujur hasil pencatatan trafo distribusi pada mobile device Android dengan perangkat GPS Garmin.

\begin{tabular}{|c|c|c|c|}
\hline Perbandingan & $\begin{array}{c}\text { Android } \\
\text { Ace2 } \\
\text { dengan } \\
\text { GPS } \\
\text { Garmin }\end{array}$ & $\begin{array}{c}\text { Tablet PC } \\
\text { Advan } \\
\text { T2V } \\
\text { dengan } \\
\text { GPS } \\
\text { Garmin }\end{array}$ & $\begin{array}{c}\text { CROSS } \\
\text { A7S } \\
\text { dengan } \\
\text { GPS } \\
\text { Garmin }\end{array}$ \\
\hline \multicolumn{4}{|c|}{ Lintang } \\
\hline Average & $-0,000309$ & $-0,000341$ & $-0,000304$ \\
\hline Max & 0,00392 & 0,00392 & 0,00404 \\
\hline Min & $-0,01069$ & $-0,01073$ & $-0,01061$ \\
\hline
\end{tabular}

\begin{tabular}{|c|r|r|r|}
\hline \multicolumn{4}{|c|}{ Bujur } \\
\hline Average & 0,0002865 & 0,0007825 & 0,000223 \\
\hline Max & 0,00723 & 0,00888 & 0,00603 \\
\hline Min & $-0,00218$ & $-0,0103$ & $-0,00455$ \\
\hline
\end{tabular}

Dari data-data yang ditunjukkan pada tabel 6 dapat dilihat bahwa nilai selisih maksimum yang didapatkan berada dibawah rentang nilai 1,0. Data ini menunjukkan bahwa hasil pengukuran data lintang dan bujur yang dilakukan oleh ketiga mobile device tersebut cukup akurat. Keakuratan ini didukung pula oleh fasilitas A-GPS yang terpasang pada masing-masing mobile device. A-GPS ditunjang server bantu sehingga A-GPS dapat bekerja secara lebih absolut dan efektif. Meskipun begitu, A-GPS pada mobile device bekerja dengan layanan LBS (Location Based Service) yang menggunakan BTS, sehingga akurasi data lintang dan bujur dapat berubah-ubah tergantung pada sinyal provider. Hal ini dapat dilihat pada pengukuran lintang pada lokasi Adi Sucipto yang memiliki kesalahan tertinggi yaitu 0,00404 melalui device CROSS A7S dan pengukuran bujur pada lokasi Cungkup - Yos Sudarso melalui device Advan Vandroid $\mathrm{T} 2 \mathrm{~V}$ yang memiliki kesalahan tertinggi 0,00888. Namun jika dilihat pada pengukuran lintang pada lokasi Diponegoro 112 yang memiliki kesalahan terendah yaitu $-0,01061$ melalui device CROSS A7S dan pengukuran bujur pada lokasi Hasanudin 100 yang memiliki kesalahan terendah 0,00218 melalui device Samsung Galaxy ACE 2, maka nilai tersebut merupakan nilai kesalahan yang sangat kecil untuk keperluan penentuan suatu lokasi trafo - 
trafo distribusi. Jadi berdasarkan data-data yang didapatkan pada tahap pengujian, penentuan posisi menggunakan mobile device Android sudah cukup akurat.

\section{KESIMPULAN}

1. Aplikasi pencatatan trafo distribusi PLN berbasis mobile device Android mampu mencatat data lintang dan bujur serta spesifikasi trafo distribusi lainnya dan menyimpan data-data tersebut pada basis data MySQL.

2. Basis data pada server berfungsi menampung datadata trafo distribusi yang dicatat dan dikirimkan secara remote dari mobile device Android dan dapat membantu inventarisasi data-data hasil pencatatan trafo distribusi.

3. Data-data lintang dan bujur hasil pencatatan trafo distribusi digunakan sebagai acuan dalam pemeliharaan trafo-trafo distribusi menurut lokasi trafo distribusi yang letaknya tersebar di seluruh wilayah layanan PLN Salatiga.

4. Data-data spesifikasi trafo distribusi (merek trafo, tahun pembuatan trafo, kapasitas trafo, lokasi trafo, deskripsi, dan petugas pencatatan trafo) dapat digunakan sebagai acuan dalam melakukan perbaikan trafo apabila terdapat kerusakan pada trafo distribusi.

5. Aplikasi pencatatan trafo pada mobile device Android, basis data MySQL, dan web trafodistribusipln.net63.net dapat terintegrasi dengan baik dan berjalan sebagai suatu sistem yang dinamis.

\section{SARAN}

1. Penelitian ini tidak berhenti sampai disini saja. Akan lebih baik apabila terus dikembangkan dan mengikuti inovasi yang ada.

2. Sistem seperti ini bisa diterapkan ke peralatan PLN yang lain yang membutuhkan penanganan data yang lebih terstruktur, tidak terbatas pada trafo distribusi saja.

\section{DAFTAR PUSTAKA}

[1] Siregar, Ivan Michael. Yusuf, Ronald. Siendow, Welly. Wino, William., 2010, "Mengembangkan Aplikasi Enterprise Berbasis Android", Penerbit Gava Media: Yogyakarta.

[2] 2011, "Aplikasi Web Database dengan Dreamweaver dan PHP-MySQL", Penerbit Andi: Yogyakarta.

[3] 2011, "Membongkar Misteri Adobe Dreamweaver CS6 dengan PHP \& MySQL”, Penerbit Andi: Yogyakarta.

[4] H., Nazruddin Safaat., 2012, "Pemrograman Aplikasi Mobile Smartphone dan Tablet PC Berbasis Android”, Penerbit Informatika : Bandung.

[5] Stallings, William., "Komunikasi Data dan Komputer (buku 1 edisi 8)", Penerbit Salemba Infotek: Jakarta.
[6] Suprianto, Dodit. Agustina, Rini., "Pemrograman Aplikasi Android Step by Step Membuat Aplikasi Android untuk Smartphone dan Tablet", Penerbit MediaKom : Yogyakarta.

[7] Rusli, Ronald., 2013, "Membuat Aplikasi GPS \& Suara Antrian dengan PHP”, Penerbit Lokomedia: Yogyakarta.

[8] Sitorus, Imzen., "Panduan Mudah menjadi Programer Web menggunakan HTML, xHTML dan CSS3", Penerbit Andi: Yogyakarta.

[9] Sulasno, Ir., 2001, "Teknik dan Sistem Distribusi Tenaga Listrik”, Universitas Diponegoro: Semarang.

[10] El-Rabbany, Ahmed., 2002, “"Introduction to GPS: the Global Positioning System”, Penerbit Ernst K\&Artech House : mobile communications series.

\section{BIODATA PENULIS}

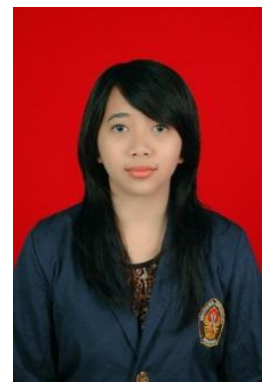

Fira Nathania, lahir di Salatiga, 30 November 1991. Telah menempuh pendidikan dasar di SD Negeri Tuntang 02 Kabupaten Semarang. Melanjutkan ke SMP Negeri 01 Salatiga, dan meneruskan Pendidikan tingkat atas di SMA Negeri 01 Salatiga, lulus tahun 2009. Dari tahun 2009 sampai saat ini tengah menyelesaikan pendidikan Strata Satu di Program Studi Teknik Sistem Komputer, Universitas Diponegoro, Semarang, Indonesia Angkatan Tahun 2009.

Menyetujui,

Dosen Pembimbing I

Ir. Kodrat Iman Satoto, M.T. NIP. 196310281993031002

Dosen Pembimbing II

Kurniawan Teguh Martono, S.T., M.T. NIP. 198303192010121002 